Vol. 11 (3): 629-632 (2021)

\title{
MEASUREMENT AND EVALUATION OF BLOOD LACTIC ACID, A REQUIREMENT FOR PREDICTING THE ANAEROBIC EXERCISE LOAD
}

\author{
K. Vrenjo ${ }^{1^{*}}$, F. Kovaci ${ }^{1}$, Dh. Skenderi ${ }^{1}$, A. Kariqi ${ }^{1}$ \\ ${ }^{1 *}$ Sports University of Tirana, Facutly of Movement Sciences, Tirana Albania; \\ *Corresponding Author Klotilda Vrenjo, e-mail: klotildavrenjo@yahoo.com;
}

Received April 2021; Accepted May 2021; Published June 2021;

DOI: $\underline{\text { https://doi.org/10.31407/ijees11.335 }}$

\begin{abstract}
The study aims to analyze the level of lactic acid in blood before a sports activity (match) and during the match. The subjects of this analysis were more than 20 football players aged 15-16, but for study purposes we considered 12 players who were active throughout the match. The Lactate SCOUT analyzer device was used to measure lactic acid before the start and a few minutes before the end of the match, the players subject of this study were measured the level of lactic acid at these two moments (T1 and T2). The average level before the match; 55.5:12=4.6 $\mathrm{mM}$. The average level after the match; 114.9:12 $=9.6 \mathrm{mM}$. The average difference; 88.2:12 $=7.35 \mathrm{mM}$. The difference of lactic acid between T1 and T2 is $9.6-4.6=5.0 \mathrm{mM}$. According to the results of this study, it is concluded that the indicators of blood lactic acid level in football players aged 15-16 are in normal parameters, about $5.0 \mathrm{mM}$, compared to the indicators of superior teams which can reach about $12 \mathrm{mM}$ during the match and about $4.0 \mathrm{mM}$ at the beginning of the match.
\end{abstract}

Keywords: lactic acid, blood, mM, football players, match. 